\title{
Investigation of platinum nanoparticle properties against U87 glioblastoma multiforme
}

Marta Kutwin ${ }^{1}$, Ewa Sawosz ${ }^{2}$, Slawomir Jaworski², Mateusz Hinzmann², Mateusz Wierzbicki², Anna Hotowy², Marta Grodzik², Anna Winnicka³, Andre Chwalibog ${ }^{4}$

\begin{abstract}
1Department of Animal Sciences, Warsaw University of Life Sciences, Warsaw, Poland ${ }^{2}$ Division of Biotechnology and Biochemistry of Nutrition, Faculty of Animal Science, Warsaw University of Life Science, Warsaw, Poland

${ }^{3}$ Department of Pathology and Veterinary Diagnostics, Faculty of Veterinary Medicine, Warsaw University of Life Sciences, Warsaw, Poland

${ }^{4}$ Department of Veterinary Clinical and Animal Sciences, University of Copenhagen, Copenhagen, Denmark
\end{abstract}

Submitted: 16 July 2015

Accepted: 30 September 2015

Arch Med Sci 2017; 13, 6: 1322-1334

DOI: $10.5114 /$ aoms.2016.58925

Copyright @ 2016 Termedia \& Banach

\section{Abstract}

Introduction: Gliomas are the most aggressive and common primary tumors of the central nervous system (CNS). Many side effects of drugs containing platinum and their poor penetration of the CNS are major drawbacks in glioma therapy. The aim of the study was to investigate and compare the toxicity of platinum nanoparticles and cisplatin and their anticancer properties in examination with a U87 glioma cell line and tumor.

Material and methods: Nanoparticles of platinum (NP-Pt) and cisplatin were incubated with U87 glioma cells or injected directly into tumor tissue. The biological properties of NP-Pt and cisplatin were compared through the morphology, viability, mortality, genotoxicity and the type of cell death of U87 glioma cells, the morphology and ultrastructure of glioma tumor, and expression of caspase-3, p53 and PCNA mRNA.

Results: NP-Pt at concentrations of $0.14 \mu \mathrm{M} / \mathrm{ml}, 0.29 \mu \mathrm{M} / \mathrm{ml}$ and $0.65 \mu \mathrm{M} / \mathrm{ml}$ had a harmful influence on viability of U87 glioblastoma multiforme (GBM) cells, but also showed genotoxic properties as well as a pro-apoptotic effect on cancer cells. It was found that NP-Pt decreased the weight and volume of U87 GBM tumor tissue and caused pathomorphological changes in the ultrastructure and morphology of tumor tissue, but they also upregulated p53 and caspase-3 mRNA expression.

Conclusions: The comparison between the effectiveness of glioblastoma treatment by NP-Pt vs cisplatin showed promising results for future studies. The results indicate that the properties of NP-Pt might be utilized for brain cancer therapy.

Key words: platinum nanoparticles, U87, glioblastoma, genotoxicity, apoptosis, cancer.

\section{Introduction}

Glioblastoma multiforme (GBM) is one of the most aggressive (WHO grade IV) neoplastic malignant tumors of the central nervous system. Malignant brain tumors are very progressive and, despite developments in neurosurgery and the strategy of chemotherapy and radiotherapy, the effectiveness of treatment is unfavorable [1]. Chemotherapy based

\author{
Corresponding author: \\ Marta Kutwin MS \\ Department of Animal \\ Sciences \\ Warsaw University \\ of Life Sciences \\ 8 Ciszewskiego St \\ 02-786 Warsaw, Poland \\ Phone: + 48662188662 \\ E-mail: \\ marta_kutwin@sggw.pl
}


on platinum compounds is most effective, but only increases the survival time of patients diagnosed with GBM [2, 3]. Cisplatin is a cytostatic and DNA-damaging drug that is widely used in firstline systemic chemotherapy against epithelial malignancies and in the second- and third-line treatment strategies against metastatic malignancies, including malignant GBM [4]. The mechanism of action of Pt-based drugs involves cell cycle arrest $[5,6]$ caused by DNA damage by $\mathrm{Pt}^{2+}$ ions, which attach to N7 sites of DNA guanine bases and, after hydrolysis of Pt-Cl bonds, the cross-links in DNA are formulated $[7,8]$. However, the major drawbacks of cisplatin are the dose-dependent side effects [9-12] and the drug resistance of GBM [4, 13]. The new GBM treatment strategies are based on the activation of the programmed cell death pathways by antineoplastic agents, including drugs, antibodies, bioactive molecules and nanoparticles [14]. Moreover, it is also very important to verify the anticancer properties of new types of bioactive molecules in in vivo models. The chicken embryo model is a suitable model to evaluate the effect of new molecules in cancer diseases and angiogenesis but also for neurotoxicity studies because at 15 days of incubation the blood brain barrier (BBB) is fully functioning [15]. The main function of the BBB is the protection of the brain tissue from substances harmful for the bloodstream. However, in cancer chemotherapy the impermeability of the BBB has an adverse impact and creates a highly specific barrier to antineoplastic drugs [16]. Furthermore, the induction of human gliomas or other types of tumor growth at the chorioallantoic membrane of chicken embryo creates permanent exposure to nanoparticles or drug activity without the possibility to remove them from the organism.

Nanoparticles of platinum (NP-Pt) have unique physiochemical and biological [11] features with regard to their small size $(<25 \mathrm{~nm})$, metal structures $\left(\mathrm{Pt}^{0}\right)$, large surface area to mass ratio [17], catalytic activity and high reactivity [18]. NP-Pt may also have different biochemical properties than platinum-based antineoplastic drugs after administration into an organism, because they are a very limited source of ions, and consequently the interaction of $\mathrm{Pt}^{(0)}$ with body fluids is significantly restricted. The potential toxic effects of NP-Pt were evaluated in in vitro healthy cells such as human [19] or chicken erythrocytes [20] and in ovo studies [11], but these biological effect where determined by nanosize of particles [21]. The results of these studies did not show harmful effects on human red blood cells or in general health indices of a chicken embryo model. On the other hand, it has also been demonstrated that, in MCF-7 and HepG-2 cancer cells, NP-Pt, synthesized from $\mathrm{K}_{2} \mathrm{PtCl}_{6}$, had dose-dependent toxicity [22]. Moreover, the combination of radiation and administration of NP-Pt in hadron cancer therapy increased the lethal DNA damage by double-strand breaks in HT29 cancer cells [24]. Lethal damage of DNA can be caused by interaction of NP-Pt coated with $\mathrm{OH}$ with phosphate groups of DNA, but the direct pathway remains unknown [6]. Although NP-Pt are also able to induce cell cycle arrest by release of $\mathrm{Pt}^{2+}$ ions after $\mathrm{H}_{2} \mathrm{O}_{2}$ generation in endosomes and cause cell apoptosis $[5,23,24]$, the introduction of NP-Pt into U87 GBM tissue has still not been documented.

We hypothesized that because of their physicochemical and biological properties, NP-Pt may be used in GBM cancer therapy. Consequently, the objective of this study was to determine potential anticancer effects of NP-Pt, with emphasis on the mechanisms of apoptosis, using GBM cells in in vitro and in vivo experiments.

\section{Material and methods}

\section{Preparation and characterization of NP-Pt and cisplatin}

Cisplatin (cis-diamineplatinum (II) dichloride) was obtained from Sigma (479306; Sigma, St. Louis, MO, USA) and diluted to $100 \mathrm{X}$ as a stock solution in ultrapure Milli-Q water. The hydrocolloid of nanoparticles of platinum (NP-Pt, high-purity metal 99.9999\%) was purchased from Nano-koloid (Warsaw, Poland). The shape and size of the NPPt were inspected using a JEM-1220 (JEOL, Tokyo, Japan) transmission electron microscope (TEM) at $80 \mathrm{KeV}$ with a Morada 11-megapixel camera (Olympus Soft Imaging Solutions, Münster, Germany). Samples for the TEM were prepared according to the scientific protocol described by Prasek et al. [11]. The zeta potential in water was measured using a Zetasizer Nano ZS model ZEN3500 (Malvern Instruments, Malvern, UK).

\section{Cell cultures and treatments}

The human glioblastoma U87 cell line was obtained from the American Type Culture Collection (Manassas, VA, USA) and maintained in Dulbecco's modified Eagle's culture medium supplemented with $10 \%$ fetal bovine serum (Sigma-Aldrich), $1 \%$ penicillin and streptomycin (Sigma-Aldrich) at $37^{\circ} \mathrm{C}$ in a humidified atmosphere of $5 \% \mathrm{CO}_{2} / 95 \%$ air in a NuAire $\mathrm{DH}$ AutoFlow $\mathrm{CO}_{2}$ Air-Jacketed Incubator (Plymouth, MN, USA). The U87 cells were incubated in a culture dish and cultivated for $24 \mathrm{~h}$ for all types of in vitro studies. NP-Pt $(0.14 \mu \mathrm{M} / \mathrm{ml} ; 0.29 \mu \mathrm{M} / \mathrm{ml} ; 0.65 \mu \mathrm{M} / \mathrm{ml})$ and cisplatin $(0.22 \mu \mathrm{M} / \mathrm{ml} ; 0.44 \mu \mathrm{M} / \mathrm{ml}, 1 \mu \mathrm{M} / \mathrm{ml})$ were added to the cells separately. The concentration of NP-Pt was equal to the atomic mass of Pt atoms in cisplatin and based on published data about anticancer properties of cisplatin [25]. Cells cultured 
without the addition of nanoparticles or cisplatin, but with the same volume of Milli-Q water, were used as the control group.

\section{Cell morphology}

After $24 \mathrm{~h}$ of exposure to the nanoparticles or cisplatin, the medium was removed and the cells were stained using the May-Grünwald-Giemsa (Sigma-Aldrich) method, and their morphology was investigated using a CKX 41 light microscope (Olympus, Tokyo, Japan). Images were captured using a ProgRes c12 camera (Jenoptik, Jena, Germany).

\section{Examination of U87 GBM cell ultrastructure by TEM}

After $24 \mathrm{~h}$ of exposure to the nanoparticles, the medium was removed and the cells $\left(5 \times 10^{3}\right.$ cells per well/six well plates) were collected and underwent the procedure described by Jaworski et al. [26].

\section{Cell viability assay}

The cell viability was evaluated using a 2,3-bis(2-methoxy-4-nitro-5-sulfophenyl)-2H-tetrazolium-5-carboxanilide salt (XTT)-based cell viability assay kit (Life Technologies, Taastrup, Denmark). U87 cells were incubated in 96 -well plates $\left(5 \times 10^{3}\right.$ cells per well) with hydrocolloids of nanoparticles of NP-Pt and cisplatin at the same concentration as for the cell morphology assay. In the next step, the XTT solution was added to each well and incubated for an additional $3 \mathrm{~h}$ at $37^{\circ} \mathrm{C}$. The optical density (OD) of each well was recorded at $450 \mathrm{~nm}$ on a scanning multi-well spectrophotometer (Infinite M200, Tecan, Durham, NC, USA). Cell viability is expressed as the percentage (ODtest ODblank)/(ODcontrol - ODblank), where "ODtest" is the optical density of cells exposed to NP-Pt and cisplatin, "ODcontrol" is the optical density of the control sample, and "ODblank" is the optical density of wells without GBM cells.

\section{Genotoxic assay - comet assay}

The genotoxicity of NP-Pt and cisplatin was evaluated using single-cell gel electrophoresis (the comet assay). U87 cells were incubated for $24 \mathrm{~h}$ in six-well plates $\left(1 \times 10^{6}\right.$ cells per well). NP-Pt $(0.29 \mu \mathrm{M} / \mathrm{ml})$ and cisplatin $(0.44 \mu \mathrm{M} / \mathrm{ml})$ were introduced to the cells separately. All the treatment groups were triplicate. Cells grown without the addition of nanoparticles were used as the control group. After $24 \mathrm{~h}$ of exposure to NP-Pt and cisplatin, the cells were collected and evaluated according to the modified procedure described by Hinzmann et al. [27]. The comets were stained using $50 \mu$ of $4^{\prime}, 6$-diamidino-2-phenylindole (DAPI;
Sigma) and viewed using a CKX 41 epifluorescent inverted microscope with a fluorescent filter, and the image was captured with a ProgRes c12 camera. At least 50 cells per group were randomly selected, photographed, and analyzed using Comet Assay Software Project software recommended by Końca et al. [28].

\section{Apoptosis assay}

Apoptosis was evaluated using the Alexa Fluor 488 Annexin V/Dead Cell Apoptosis Kit with Alexa Fluor 488 Annexin $V$ and propidium iodide (PI) for flow cytometry (Life Technologies). U87 GBM cells $\left(1 \times 10^{5}\right.$ cells per well) were incubated for $24 \mathrm{~h}$. Then the medium was removed, and NP-Pt $(0.29 \mu \mathrm{M} / \mathrm{ml})$ and cisplatin $(0.44 \mu \mathrm{M} / \mathrm{ml})$ in the culture medium were added to the cells and incubated for an additional $24 \mathrm{~h}$. The positive control was prepared as described by Jaworski et al. [26]. U87 cells were harvested, washed in cold PBS and transferred to tubes and stained with the Annexin V/PI staining protocol (Life Technologies). U87 GBM cells were analyzed by flow cytometry (FACSCalibur, Becton Dickinson, Franklin Lakes, NJ, USA), measuring the fluorescence emission at $530 \mathrm{~nm}$ and $575 \mathrm{~nm}$ (or equivalent) using excitation at $488 \mathrm{~nm}$. The positive cells were identified on the basis of the fluorescence intensity of Annexin V-Alexa Fluor 488 (early stage of apoptosis) or PI (end stage of apoptosis and necrosis). Data were analyzed using Cell Quest Pro software (Becton Dickinson), and the regions were set on the basis of positive and negative control samples.

\section{Culture of GBM on chorioallantoic membranes}

The fertilized eggs (Gallus gallus; $n=60$ ) were supplied by a commercial hatchery (Debowka, Poland). After 6 days of egg incubation, the silicone ring with the deposited 3-4 × $10^{6}$ U87 cells suspended in $30 \mu \mathrm{l}$ of culture medium was placed on the chorioallantoic membrane according to the procedure of Grodzik et al. [29]. The eggs were incubated for 7 days, and then 36 eggs with visible tumor development were chosen. Eggs were divided into three groups of 12: the control group, the NP-Pt group $(8.45 \mu \mathrm{M} / \mathrm{ml})$ and the cisplatin group $(13 \mu \mathrm{M} / \mathrm{ml})$. The eggs were injected with $200 \mu$ l of solutions of NP-Pt and cisplatin, as proposed by Cemazar et al. [30]. The solutions were added directly into the tumors. The concentration of NP-Pt was equal to the atomic mass of Pt atoms in cisplatin. After 2 days, the tumors were resected for further analysis.

\section{Calculation of tumor volume}

Digital images of tumors were taken by a stereomicroscope (SZX10, CellD software version 3.1; 
Olympus Corporation, Tokyo, Japan). The measurements of volume were taken with cellSens Dimension Desktop version 1.3 (Olympus). The tumor volumes were calculated with the equation:

$$
V=\frac{4}{3} \pi r^{3},
$$

where $r=\frac{1}{2} \sqrt{\text { diameter } 1 \times \text { diameter } 2}, \pi=3.1415$.

\section{Examination of U87 GBM tissue morphology}

The tumor tissues from control, NP-Pt and cisplatin treated groups were sampled and fixed in $10 \%$ buffered formalin ( $\mathrm{pH}$ 7.2). Fixed samples were dehydrated in a graded series of ethanols, embedded in Paraplast, and cut into $5 \mu \mathrm{m}$ sections using a microtome (Leica RM 2265, Leica, Nussloch, Germany). The morphology of the chicken brains was examined using hematoxylin-eosin $(\mathrm{H}+\mathrm{E})$ staining.

\section{Examination of U87 GBM tumor tissue ultrastructure by TEM}

For the evaluation of ultrastructure of tumor tissues from the control, NP-Pt and cisplatin group samples were fixed for TEM in fixative consisting of $1 \%$ glutaraldehyde in $\mathrm{PBS}$ at $\mathrm{pH}$ 7.2. After fixation, the tumor tissues were post-fixed in $1 \%$ osmium tetroxide and dehydrated in a graded series of ethanol. The pellets were embedded in a mixture of Araldite and Epon. Ultrathin sections $(100 \mathrm{~nm})$ were cut on an ultramicrotome (EM UC6, Leica).

\section{mRNA expression of caspase-3, p53 and PCNA}

Gene expression at the mRNA level was measured in tumor tissue samples treated with NP-Pt or cisplatin using quantitative polymerase chain reaction (PCR). The tissue tumor samples were homogenized in TRIzol reagent (Invitrogen, Carlsbad, CA, USA) using TissueLyser II (Qiagen, Venlo, Netherlands), and total RNA was extracted according to the manufacturer's instructions. The RNA samples were purified using the SV Total RNA Isolation System (Promega, Fitchburg, WI, USA). The total RNA concentration was quantified using a NanoDrop ND 1000 spectrophotometer (NanoDrop Technologies, Wilmington, DE, USA). For each sample, $200 \mathrm{ng}$ of total RNA was reverse transcribed using reverse transcriptase (Promega, Madison, WI, USA), oligo-dT and random primers (TAG Copenhagen A/S Symbion, Copenhagen, Denmark). The real-time PCR was performed with cDNAs and gene-specific primer pairs (TAG Copenhagen A/S Symbion; Table I) using SYBR Green I detection and the LightCycler System 480 SYBR Green I Master (Roche Diagnostics, Basel, Switzerland). The samples were denatured for $5 \mathrm{~min}$ at $95^{\circ} \mathrm{C}$, amplified using 45 cycles of $10 \mathrm{~s}$ at $95^{\circ} \mathrm{C}$ (denaturation), $10 \mathrm{~s}$ at $60^{\circ} \mathrm{C}$ to $62^{\circ} \mathrm{C}$ (annealing) and $9 \mathrm{~s}$ at $72^{\circ} \mathrm{C}$ (elongation), followed by quantification. All reactions were performed in triplicate. For all analyses, relative quantification was applied, and the housekeeping genes were $\beta$-actin (ACTB) and elongation factor $1 \alpha 2$ (EEF1A2).

\section{Confocal immunofluorescent analysis of p53 and caspase- 3 protein level}

For the confocal immunofluorescent analysis, gliomas tissue samples were frozen in Jung Tissue Freezing Medium (Leica, Wetzlar, Germany) in liquid nitrogen and cut into $5 \mu \mathrm{m}$ thick sections using a cryostat (CM 1900, Leica, Wetzlar, Germany). The sections were attached to poly-l-lysine coated microscope slides. Tissue was washed with PBS and permeabilized with $0.5 \%$ Tween 20 (Sigma, St. Louis, USA) PBS solution for $10 \mathrm{~min}$. The sections were blocked with PBS containing $2 \%$ goat serum and $1 \%$ bovine serum albumin (Sigma, St. Louis, USA) for $30 \mathrm{~min}$. Sections were incubated with primary antibody rabbit anti caspase- 3 antibody (269518, Novus Biologicals, LLC, Southpark Way, CO, USA) and mouse anti-p53 (PAb 240, Novus Biologicals) diluted in $2 \%$ goat serum (producer recommended dilution) for $12 \mathrm{~h}$ at $4^{\circ} \mathrm{C}$. After caspase- 3 and p53 localization in glioma tumor tissue, washed sections were incubated with secondary antibody: for caspase- 3 goat anti-rabbit Atto 488 conjugate (Cell Signaling Technology, Danvers, USA) and for p53 goat anti-mouse FITC 488 conjugate (Sigma, St. Louis, USA) for 2 h, diluted according to the producer's instructions. Nuclei were stained by incubation with 4',6-di-

Table I. Primer sequences for the investigated genes

\begin{tabular}{|lcc|}
\hline Target gene & Forward primer & Reverse primer \\
\hline Caspase-3 & CAAACTTTTTCAGAGGGGATCG & GCATACTGTTTCAGCATGGCAC \\
\hline p53 & GTTCCGAGAGCTGAATGAGG & TTATGGCGGGAGGTAGACTG \\
\hline PCNA & AGGCACTCAAGGACCTCATCA & GAGTCCATGCTCTGCAGGTTT \\
\hline EEF1A2 & AGCAGACTTTGTGACCTTGCC & TGACATGAGACAGACGGTTGC \\
\hline ACTB & GTCCACCTTCCAGCAGATGT & ATAAAGCCATGCCAATCTCG \\
\hline
\end{tabular}




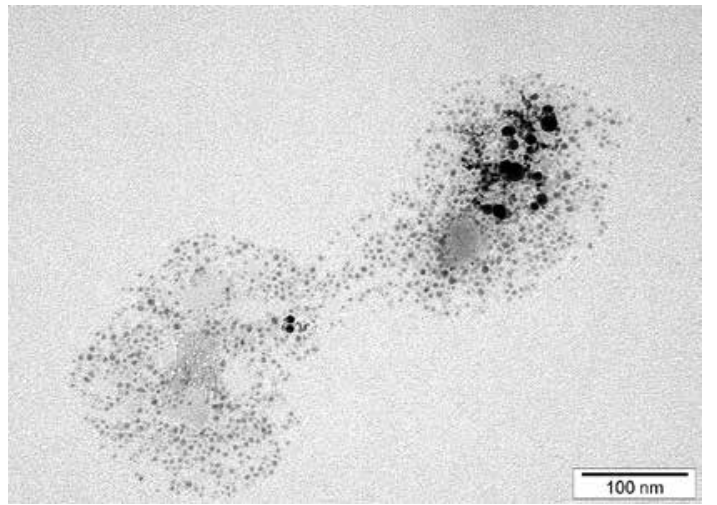

Figure 1. TEM images of NP-Pt. Scale bar: $100 \mathrm{~nm}$

amidino-2-phenylindole (DAPI) solution for 15 min (Sigma, St. Louis, USA). After washing the coverslips were mounted on slides with Fluoromount mounting medium (Sigma, St. Louis, USA) and observed on a IX 81 FV-1000 confocal microscope (Olympus Corporation, Tokyo, Japan). Image analysis in confocal mode, Nomarski interference contrast, and cell counting were performed using FVIO-ASW ver. 1.7c software (Olympus Corporation, Tokyo, Japan). Three-dimensional images were assembled from 30 optical sections.

\section{Statistical analysis}

Data were analyzed using one-way analysis of variance (ANOVA) with Statgraphics Plus 4.1
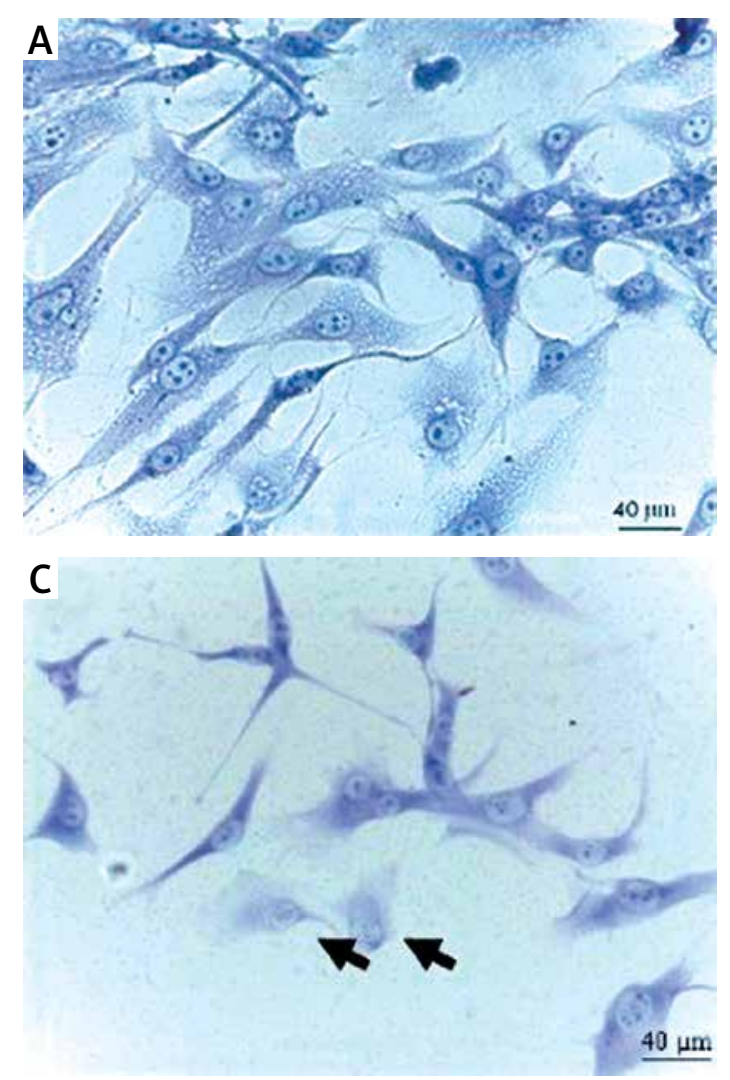

(StatPoint Technologies, Warrenton, VA, USA). The differences between groups were tested using Tukey's multiple range tests. All mean values are presented with the standard deviation.

\section{Results}

\section{Characterization of NP-Pt}

NP-Pt had a regular round shape, and the diameter of the particles ranged from $2 \mathrm{~nm}$ to $19 \mathrm{~nm}$ (Figure 1). Agglomeration of NP-Pt colloids was not detected. The mean zeta potential of NP-Pt was -27.86 .

\section{Cell morphology}

U87 GBM cells from the control group had the characteristic morphology with long branched protrusions. Compared to the control, the results showed that NP-Pt $(0.14 \mu \mathrm{M} / \mathrm{ml} ; 0.29 \mu \mathrm{M} / \mathrm{ml} ; 0.65$ $\mu \mathrm{M} / \mathrm{ml})$ and cisplatin $(0.22 \mu \mathrm{M} / \mathrm{ml} ; 0.44 \mu \mathrm{M} / \mathrm{ml}$; $1 \mu \mathrm{M} / \mathrm{ml}$ ) treatment decreased the number of cells and reduced the length of cell protrusions (Figure 2).

\section{Cell ultrastructure}

U87 GBM cell ultrastructure assays showed that NP-Pt and cisplatin treatments affected mitochondrial structure, causing deformation of the inner membrane and cristae (Figure 3). NP-Pt induced the vacuolization process and degradation of the structure of the cytoskeleton of the GBM

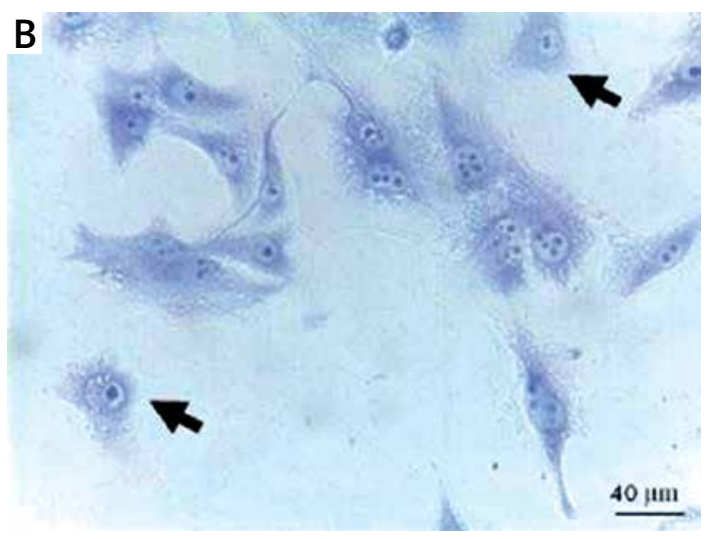

Figure 2. Morphology of U87 glioma cells. A - untreated cells (control group), B - cells treated with NP-Pt $(0.29 \mu \mathrm{M} / \mathrm{ml})$, and $\mathrm{C}-$ cisplatin treated cells $(0.44 \mu \mathrm{M} / \mathrm{ml})$. Black arrows point to cells with incorrect morphology. May-Grünwald staining method. Light optical microscopy. Scale bars: $40 \mu \mathrm{m}$ 

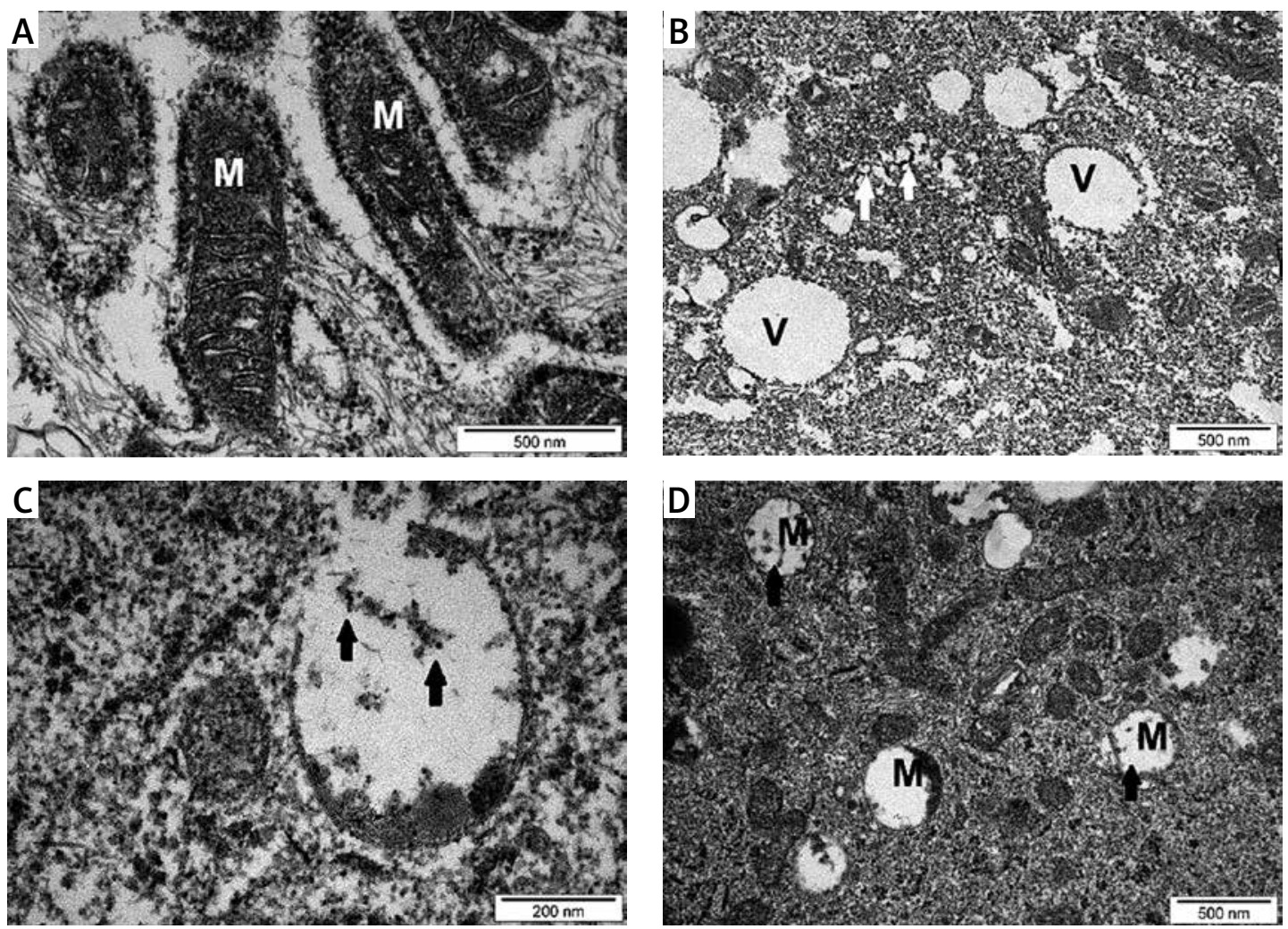

Figure 3. TEM evaluation of U87 glioma cells. A - untreated cells (control group), B and C - U87 cells treated with $0.29 \mu \mathrm{M} / \mathrm{ml}$ of NP-Pt, D - U87 cell treated with $0.44 \mu \mathrm{M} / \mathrm{ml}$ of cisplatin

$M$ - mitochondria, $V$-vacuoles. Black arrows - point to complexes of DNA and NP-Pt (C) or cisplatin (D). White arrows point to cytoskeleton deformation. A, B, D scale bars $-500 \mathrm{~nm}$, C scale bar $-200 \mathrm{~nm}$.

cells. Compared to the cells treated with cisplatin, the TEM images of cells treated with nanoparticles showed that NP-Pt have strong affinity to mitochondria (Figure 3).

\section{Cell viability}

The XTT cell viability assay is based on the ability of living and metabolically active cells to reduce the tetrazolium salt XTT into the orange formazan product. The results showed that GBM cells treated with NP-Pt and cisplatin had decreased metabolic activity compared to the untreated GBM cells. Furthermore, increased concentration of NP-Pt resulted in linear decreased cell vitality at a comparable level to cisplatin (Figure 4).

Genotoxic activity of NP-Pt as determined by the comet assay

Genotoxic activity assessed by the comet assay (Figure 5) showed formation of comets in cells treated with NP-Pt $(0.29 \mu \mathrm{M} / \mathrm{ml})$ and cisplatin $(0.44 \mu \mathrm{M} / \mathrm{ml})$. In contrast, cells from the control group did not form any comets (Figure 5). The level of genotoxicity of NP-Pt and cisplatin, illustrated by tail DNA percentage, was not significantly different (Figure 5).

\section{Apoptosis assay}

The annexin V/PI a ssay is an effective method for detecting the type of cell death by detecting the location of phosphatidylserine on cell membranes. The detection process is possible by monitoring the phosphatidylserine location by annexin $V$, which has a strong and specific affinity to phosphatidylserine. NP-Pt and cisplatin treatments of U87 GBM cells increased the amount of cell death and induced apoptosis (Figure 5). The level of apoptosis-positive cells was higher after cisplatin

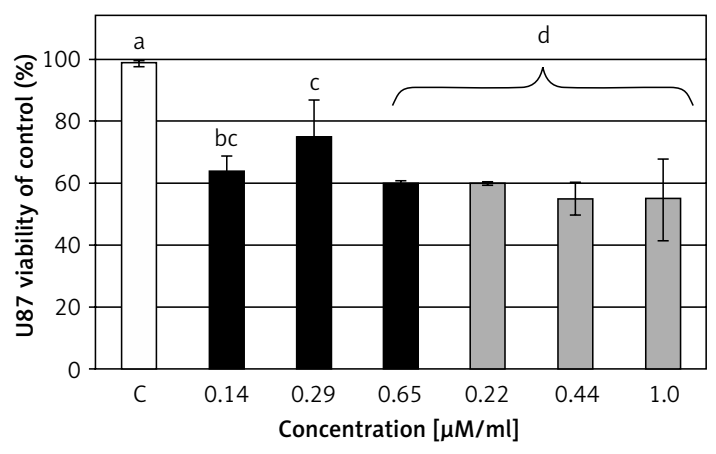

Figure 4. Cell viability - XTT assay. Effect of NP-Pt (black bars) and cisplatin (grey bars), and untreated cells (white bars) on the viability of U87 glioma cells

The columns with different letters $a, b, c, d i n d i c a t e ~ s i g n i f i c a n t$ differences between the concentrations $(p<0.05)$. 

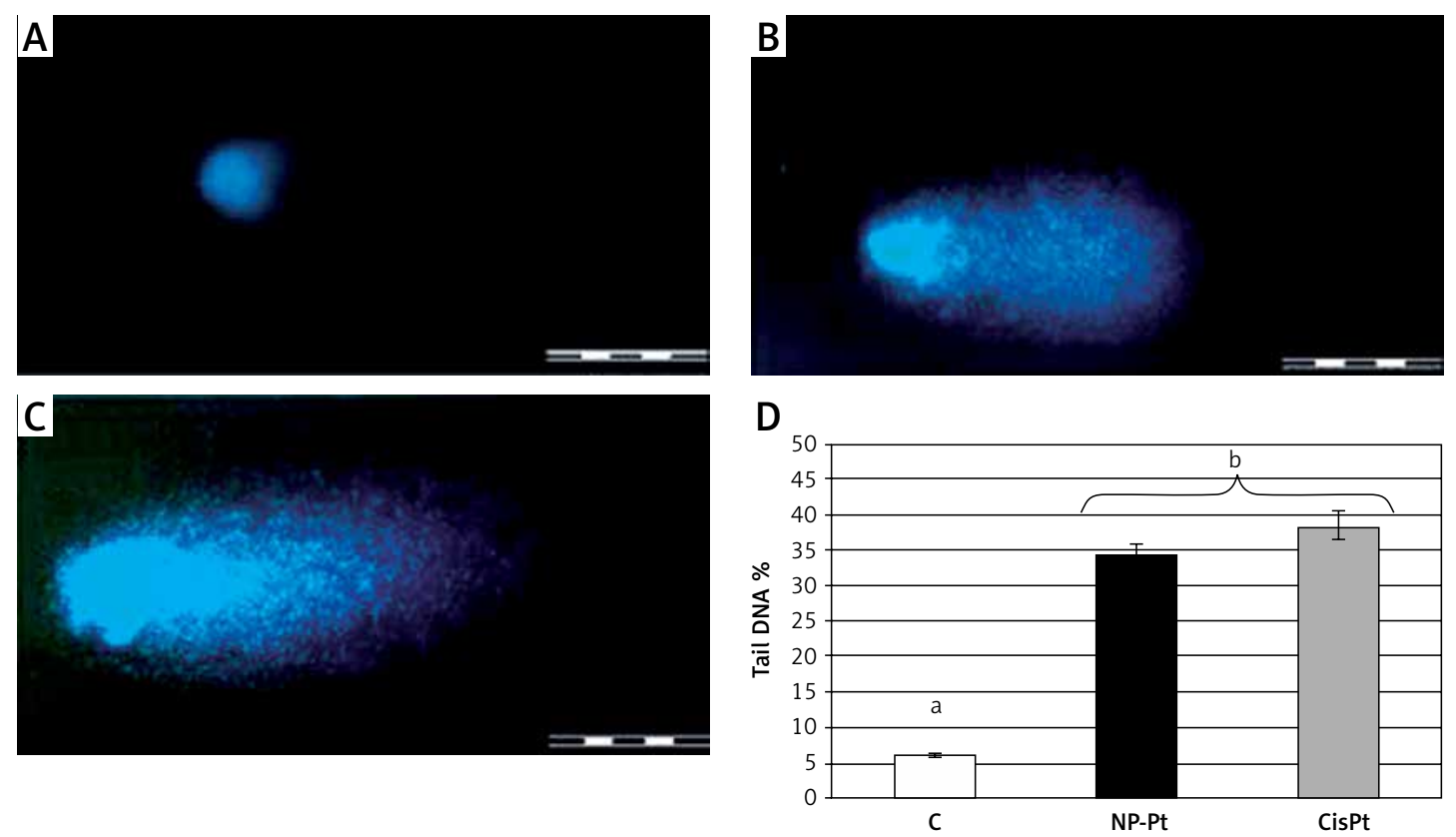

$E$

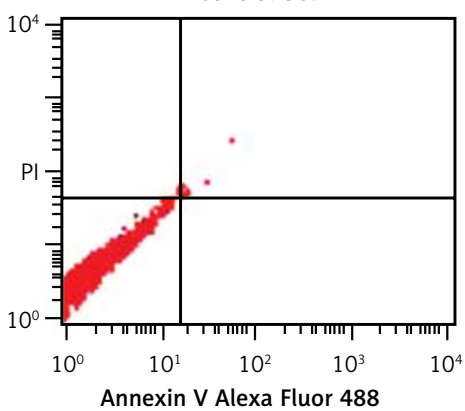

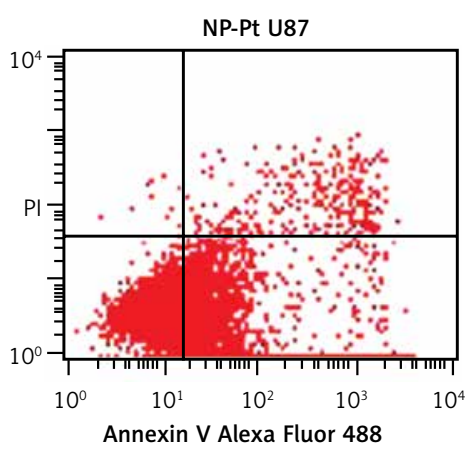

Annexin V Alexa Fluor 488

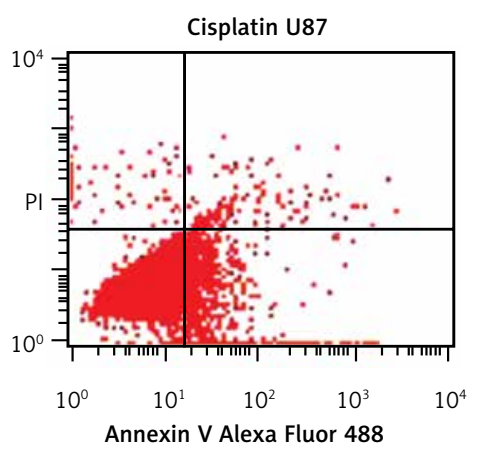

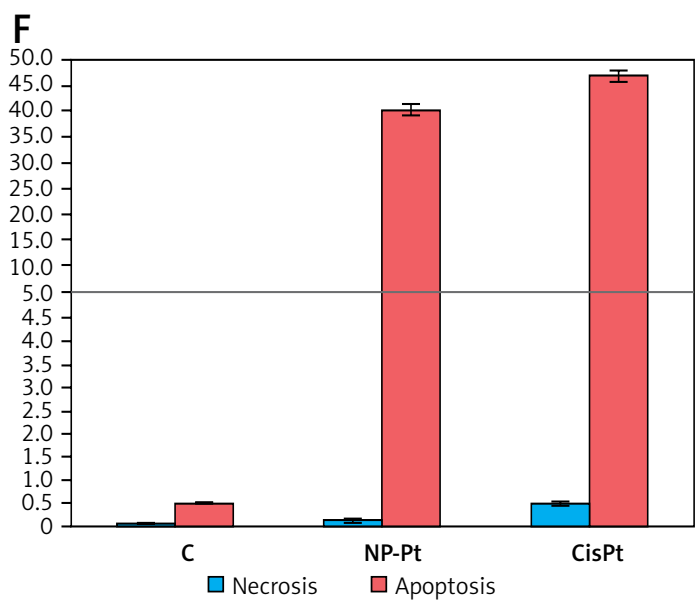

Figure 5. Genotoxic and proapoptotic properties of NP-Pt. A, B, C - comets from single-cell gel electrophoresis stained with DAPI (4', 6-diamidino-2-phenylindole). A - untreated U87 cells, and treated with: B - platinum nanoparticles $(0.29 \mu \mathrm{M} / \mathrm{ml}), \mathbf{C}$ - cisplatin $(0.44 \mu \mathrm{M} / \mathrm{ml})$. Scale bars $500 \mu \mathrm{m}$. D - Tail DNA percentage. $\mathbf{C}-$ untreated U87 cells and treated with NP-Pt - platinum nanoparticles and cisplatin. D - the columns with different letters a,b indicate significant differences between groups $(p<0.05)$. Flow cytometry Annexin V-Alexa Fluor 488 and propidium iodide (PI) assay: E - scatter diagrams of U87 GBM cells exposed to platinum nanoparticles (0.29 $\mu \mathrm{M} / \mathrm{ml})$ and cisplatin $(0.44 \mu \mathrm{M} / \mathrm{ml})$. F - Rate of necrosis (blue bars) and apoptosis (red bars) in U87 GBM cells

Control group - untreated cells, NP-Pt-platinum nanoparticles. 
Table II. Characteristics of glioblastoma multiforme U87 tumors treated with NP-Pt and cisplatin

\begin{tabular}{|lccccc|}
\hline Parameter & \multicolumn{3}{c|}{ Group } & \multicolumn{2}{c|}{ ANOVA } \\
\cline { 2 - 6 } & C & NP-Pt & Cisplatin & P-value & SE-pooled \\
\hline Volume $\left[\mathrm{mm}^{3}\right]$ & $92.8^{\mathrm{a}}$ & $43.5^{\mathrm{b}}$ & $53.9^{\mathrm{ab}}$ & 0.002 & 73.67 \\
\hline Weight $[\mathrm{mg}]$ & $103.3^{\mathrm{a}}$ & $60.4^{\mathrm{b}}$ & $41.9^{\mathrm{b}}$ & 0.002 & 22.01 \\
\hline
\end{tabular}

${ }_{a, b}$ Values within rows with different superscripts are significantly different. U87 glioma tumors treated with platinum nanoparticles $(\mathrm{NP}$-Pt $0.29 \mu \mathrm{M} / \mathrm{ml})$ and cisplatin $(0.44 \mu \mathrm{M} / \mathrm{ml})$, and control (untreated tumor). C - control group, NP-Pt-platinum nanoparticles, ANOVA - analysis of variance, SE - standard error.

treatment (58\%) than after the NP-Pt treatment (51\%). The degree of necrosis was the highest in GBM cells after cisplatin treatment, while the number of necrotic cells after NP-Pt was lower (Figure 5).

\section{GBM tumor tissue - volume, weight and morphology after treatment with NP-Pt and cisplatin}

The GBM cells were cultivated on chorioallantoic membranes. After resection of tumor tissue, the volume, weight and morphology were compared. NP-Pt and cisplatin treatments significantly decreased the volume and weight of tumors compared to the control group. There were no differences between treatment groups (Table II, Figure 6). The evaluation of the cross section of glioma tumor tissue stained by the $\mathrm{H}+\mathrm{E}$ method showed that after NP-Pt injection the cell density was decreased and the tumor lost the compact structure of the tissue. Comparing the efficiency of anticancer properties of NP-Pt vs. cisplatin, after the cisplatin treatment the morphology of tumor tissue showed the higher density of cells (Figure 6). Moreover, the cross section of tumor tissue also showed the typical presence of various types of cells: large, small, multinuclear cells and cells with atypical morphology of nuclei.

\section{GBM tumor ultrastructure}

The GBM tumor examination of ultrastructure by TEM showed that NP-Pt had a toxic effect on tissue structure causing deformation of the mitochondrial inner membrane and also interacting with mitochondria genetic materials (Figure 7). Moreover, NP-Pt were present on the mitochondrial membrane. TEM images showed that NP-Pt treatment also had an impact on the vacuolization process of tumor GBM tissue.

\section{mRNA expression of caspase-3, p53 and PCNA}

The level of mRNA expression of caspase- 3 increased after the NP-Pt and cisplatin treatments of the U87 GBM tumor (Table III). The differences were significant compared to the control group, but were not different between NP-Pt and cispla- tin. Similar results were observed for $p 53$ mRNA expression. The level of mRNA expression of caspase- 3 and $p 53$ showed that intratumoral injection of NP-Pt and cisplatin induced the apoptosis pathway of the GBM tumor. The level of cell proliferation was verified by evaluation of PCNA mRNA expression, which showed a tendency towards decreasing PCNA expression after both treatments compared to the control group.

\section{Confocal microscopy - p53 and caspase-3 protein level}

The investigation of $\mathrm{p} 53$ protein level in a cross section of glioma tumor tissue showed significantly increased expression of p53 observed in cytoplasm and nuclei stained with p53 antibody conjugated with FITC (Figure 8 A). Similar findings were observed after evaluation of caspase-3 protein level (Figure $8 \mathrm{~B}$ ). Cisplatin treatment of glioma tumor also increased the p53 as well as caspase-3 protein level in U87 glioma tissue.

\section{Discussion}

The results of our studies indicate that NP-Pt decreased the U87 GBM cell viability. Furthermore, the treatment with NP-Pt was compared to cisplatin, and the effectiveness of the treatments did not differ significantly despite the same dose of $\mathrm{Pt}^{2+}$ ions in cell treatment. The new perspective of usage in cancer treatment of platinum nanoparticles programmed to activate the cell death pathways are promising for patients diagnosed with cancer diseases. However, without the proper diagnostic tools, including innovative molecular imaging of brain tumor, the treatment strategy may be inefficient [31, 32]. Molecular evaluation of gliomas can also maximize treatment efficacy, decrease the gap between the primary in vitro and preclinical in vivo research, and can help to improve the anticancer properties of molecules against selected types of cells [33]. The NP-Pt treatment results confirmed the previous report [5] about the interaction of human cells with NP$\mathrm{Pt}$, in which nanoparticles also entered the cells, decreasing the metabolic activity and inducing cell death. The present results are in line with studies with different types of cancer cells that demon- 

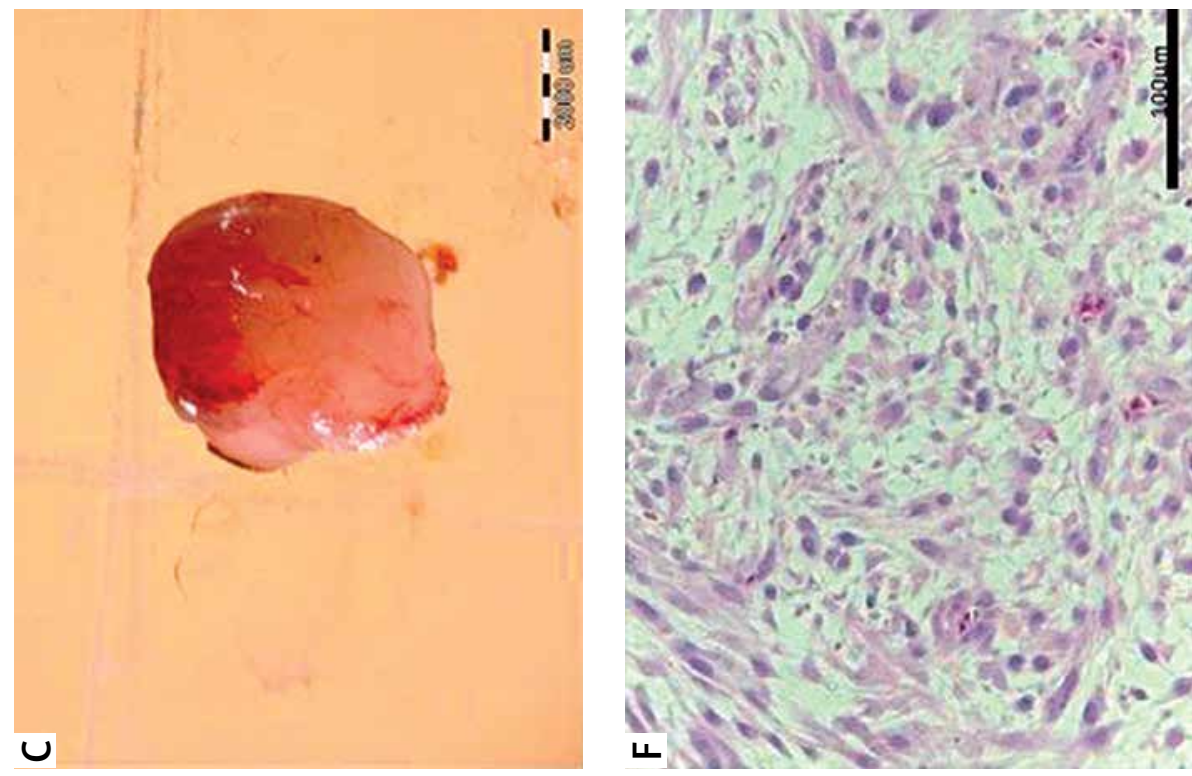

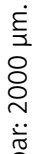
$\frac{\sqrt{2}}{\stackrel{\frac{\pi}{0}}{\frac{\pi}{2}}}$
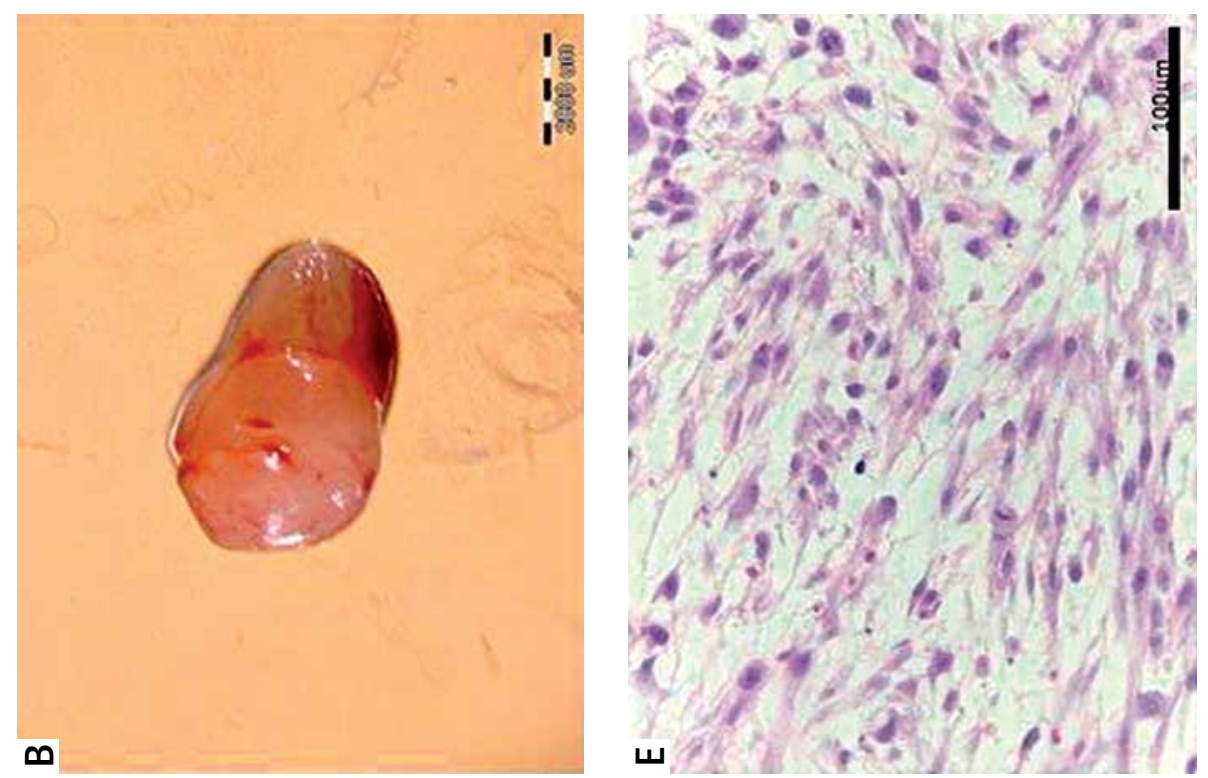
芩 $\frac{\circ}{\frac{0}{\partial}}$

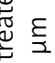
竞 i $\frac{\pi}{2}$ 㻤 号 ज
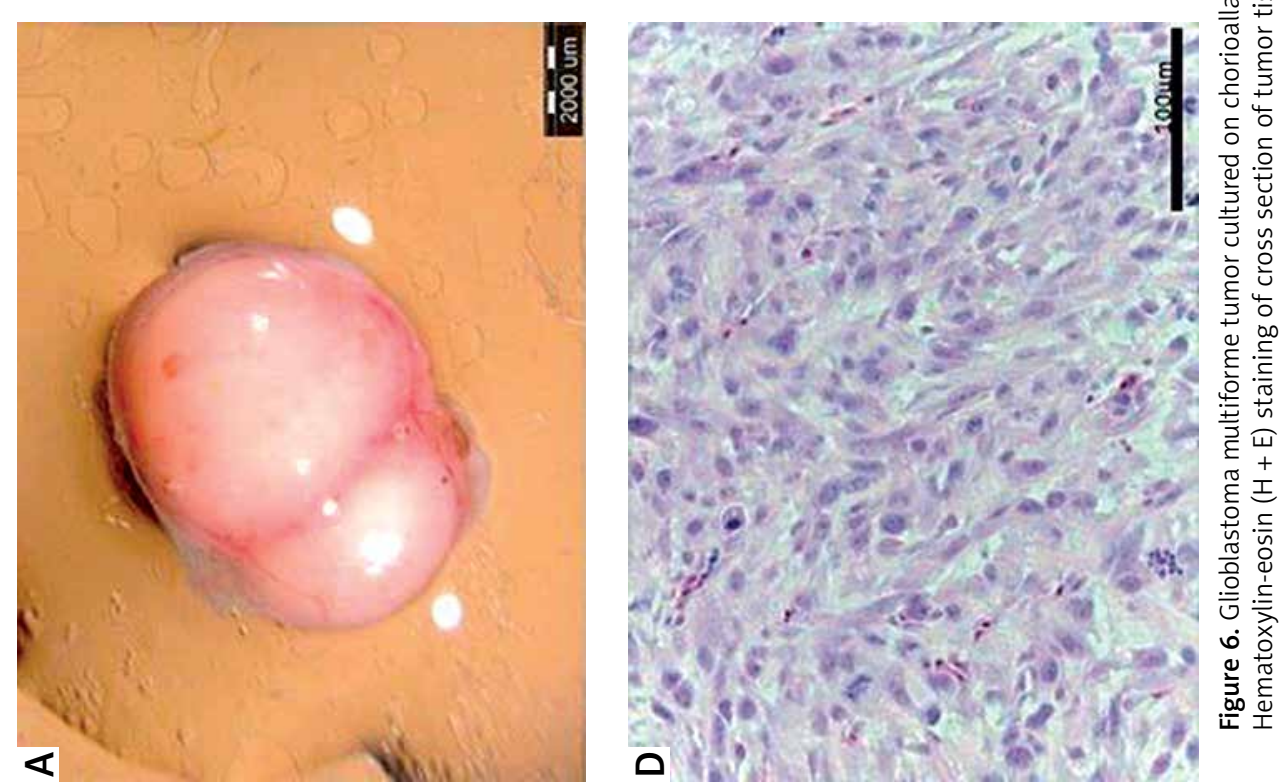

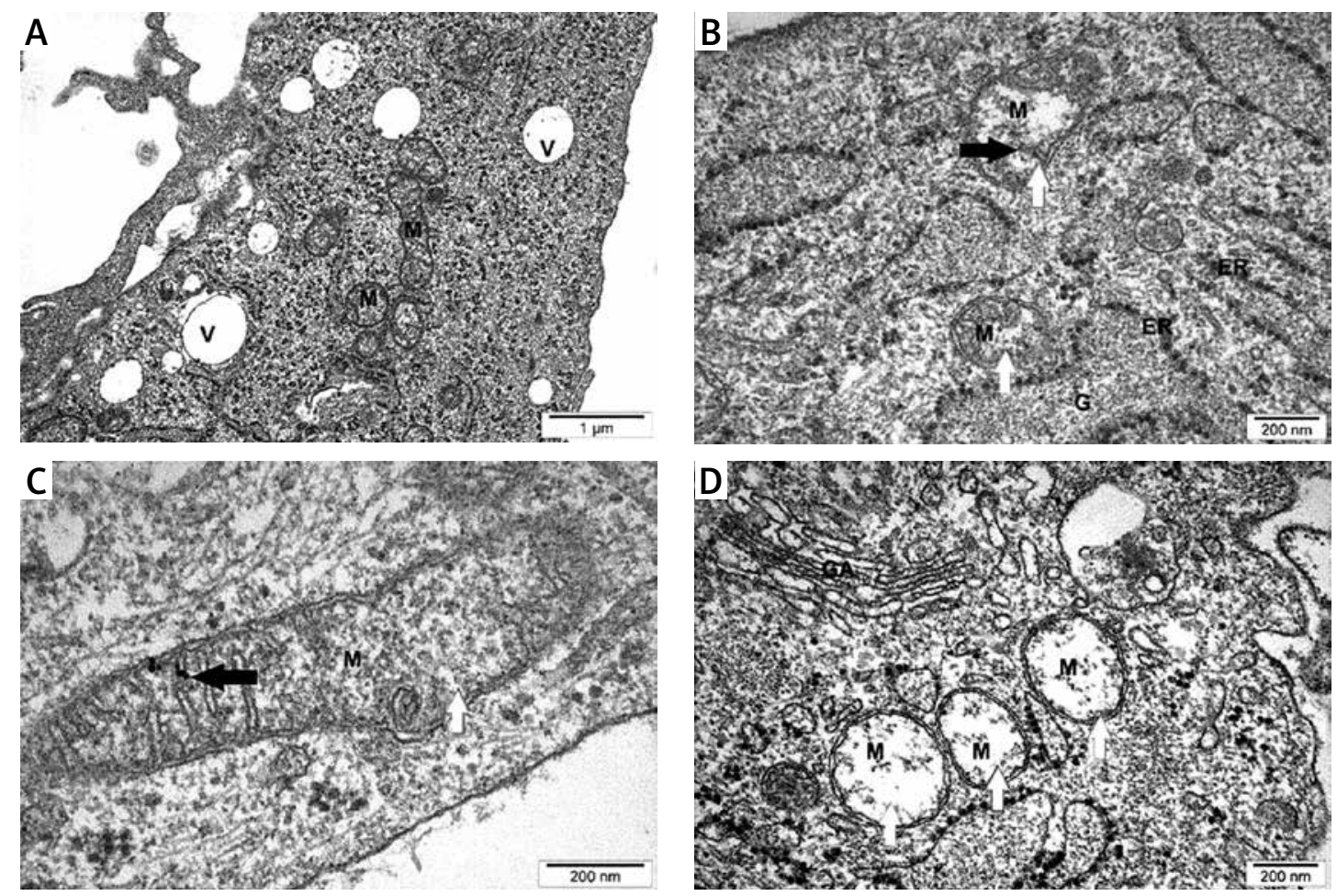

Figure 7. TEM evaluation of U87 glioma tumors. A - untreated tumors (control group), B and C - U87 tumors treated with $8.45 \mu \mathrm{M} / \mathrm{ml}$ of NP-Pt, $\mathbf{D}$ - U87 tumors treated with $13 \mu \mathrm{M} / \mathrm{ml}$ of cisplatin

$M$ - mitochondria, $V$-vacuoles, GA - Golgi apparatus, ER-endoplasmic reticulum, $G$ - glycogen. Black arrows - point to complexes of DNA and NP-Pt (C). White arrows point to mitochondrial deformation. A, B, D scale bars: $500 \mathrm{~nm}, C-$ scale bar: $200 \mathrm{~nm}$.

Table III. Caspase-3, p53, and PCNA gene expression profile in glioblastoma multiforme tumors following platinum nanoparticles (NP-Pt) and cisplatin treatment

\begin{tabular}{|lccccc|}
\hline $\begin{array}{l}\text { Level of mRNA } \\
\text { expression }\end{array}$ & Control & Groups & \multicolumn{2}{c|}{ ANOVA } & \multirow{2}{*}{ SE-pooled } \\
\cline { 2 - 5 } & $0.437^{\mathrm{a}}$ & $1.035^{\mathrm{b}}$ & $0.950^{\mathrm{b}}$ & 0.012 & 0.107 \\
\hline Caspase-3/EEF1A2 & $0.345^{\mathrm{a}}$ & $0.754^{\mathrm{b}}$ & $0.589^{\mathrm{ab}}$ & 0.004 & 0.056 \\
\hline p53/EEF1A2 & 0.744 & 0.554 & 0.673 & 0.147 & 0.066 \\
\hline PCNA/EEF1A2 & & Cisplatin & -value & \\
\hline
\end{tabular}

${ }_{a, b}$ Values within rows with different superscripts are significantly different, $p<0.05$. Values were normalized to the housekeeping gene EEF1A2. NP-Pt - platinum nanoparticles, ANOVA - analysis of variance, SE - standard error.

strated decreased viability of cells treated with NP-Pt [22-24, 34, 35].

The evaluation of the ultrastructure of U87 GBM cells showed that NP-Pt were able to cross the cell membrane, penetrate the cell body and adhere especially to mitochondria. These results partly confirmed previous findings, demonstrating that NP-Pt were able to cross HT29 cell membranes, but the cellular localization of NP-Pt was different, as nanoparticles were located mainly in the cytoplasm [23]. In our studies, NP-Pt were located close to nucleic acids, which might encourage platinum-DNA chemical reactions. One of the treatment strategies of GBM, based on cisplatin, involves DNA damage by formation of DNA intraand inter-strand breaks and activation of the cell death pathway [7, 33]. However, drug resistance of gliomas [2] and side effects of platinum-based drugs including hepatotoxicity, ototoxicity and nephrotoxicity are major drawbacks in GBM therapy $[4,7,8]$. It has been reported that NP-Pt did not show harmful effects on general health after administration into an organism [11]. Moreover, in our studies, not only was the phenomenon of affinity of NP-Pt to DNA observed, but also the genotoxic properties of NP-Pt were verified. The present results of genotoxicity evaluation based on the tail DNA length of formulated comets showed that NP-Pt, as well as cisplatin at the same concentration of Pt, caused lethal damage of DNA. In addition, DNA destruction can also be the result of the formation of DNA double-strand breaks by $\mathrm{Pt}^{2+}$ ions released from NP-Pt [24]. The results also demonstrated that the lethal DNA damage of U87 GBM cells induced apoptosis. The investigation of NP-Pt apoptotic properties showed that U87 GBM 

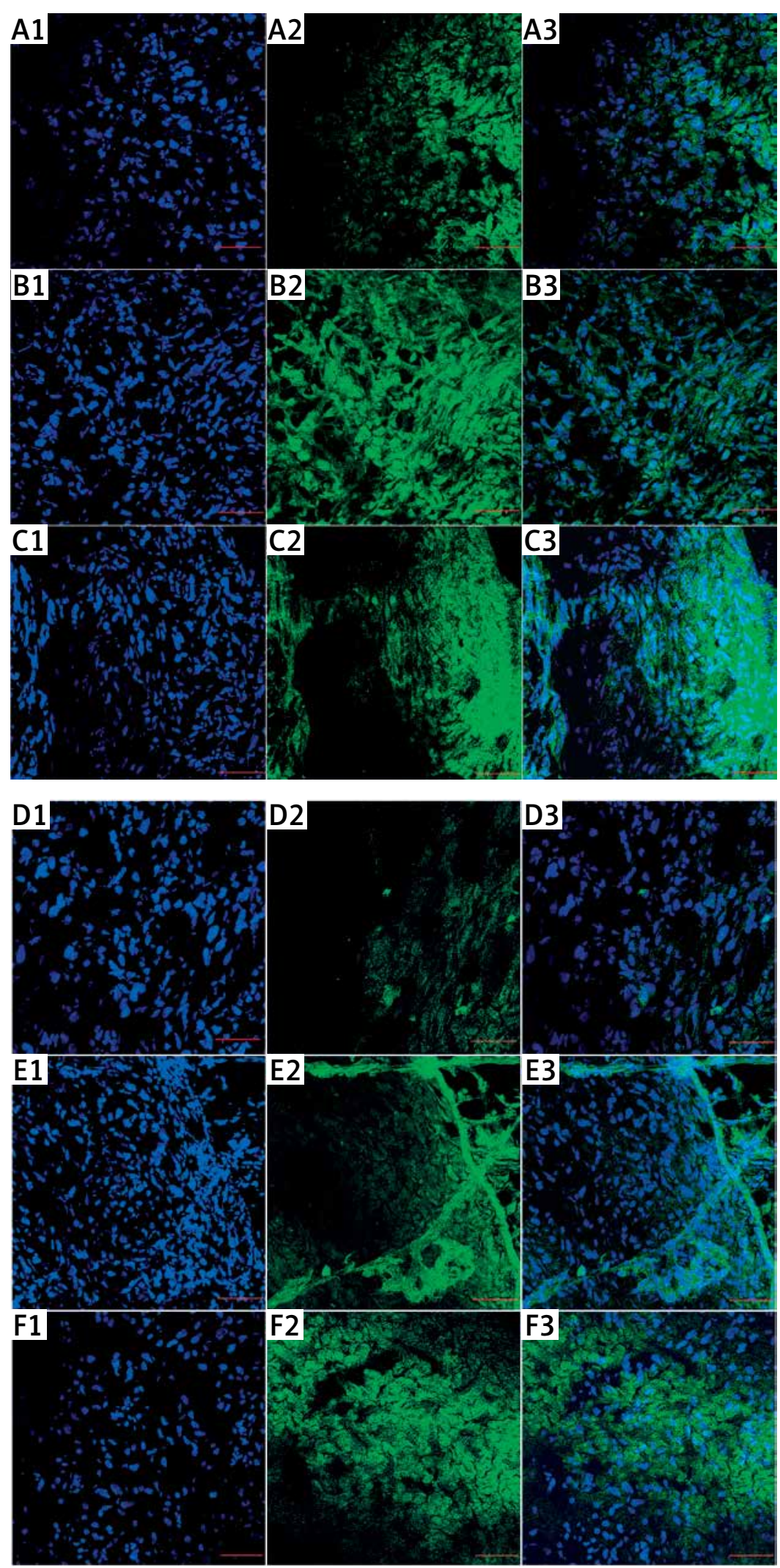

Figure 8. Protein expression level of $p 53$ and caspase-3. Visualization of $p 53$ (A, B, C) and caspase-3 (D, E, F) in glioblastoma tumors, shown as an overlaid image of 4',6-diamidino-2-phenylindole-stained nuclei (blue (A1, B1, C1, D1, E1, F1)) and cytoplasm p53 stained with fluorescent secondary antibody 488 FITC (green) (A2, B2, C2), and caspase-3 stained with fluorescent secondary antibody 488 Alexa Fluor (green) (D2, E2, F2), in the cross-section of the tumors, visualized using a confocal microscope

A1-3, D1-3-control group, B1-3, E1-3-nanoparticles of platinum, C1-3, F1-3-cisplatin. Scale bars: $100 \mu \mathrm{m}$. 
cells treated with NP-Pt underwent apoptosis at a significantly higher level than those treated with cisplatin. Introducing NP-Pt to the U87 GBM cells also showed that the level of necrosis was lower than in the cisplatin-treated cells. Moreover, the significantly increased expression of $p 53$ and a tendency towards decreasing PCNA expression by NP-Pt treatment of human cells caused inhibition of the cell cycle and induced apoptosis pathways [5].

To assess the potential anticancer properties of NP-Pt the in ovo U87 tumor model was adopted. The volume and weight of the tumor were significantly reduced compared to the untreated tumor. Moreover, the morphology of a cross section of tumor tissue showed decreased density of tumor cells, pointing to potential anticancer properties of NP-Pt. Similar results were obtained with the $\mathrm{C} 6 \mathrm{GBM}$ tumor treated with $\mathrm{H}_{2} \mathrm{PtCl}_{6} / \mathrm{TiO}_{2}$ nanoparticles, where reduction of tumor weight and decreased aggressiveness were detected [6]. However, the effect of NP-Pt treatment of the U87 GBM tumor changed not only the morphology of the tumor tissue but also the degradation of mitochondria, and increased the number of vacuoles in the tumor tissue. The number of changed structures visualized in the U87 GBM ultrastructure confirms the in vitro results, indicating the induction of GBM cell death by NP-Pt. In addition, the upregulation of mRNA and increased protein expression level of caspase- 3 and p53 by the NP-Pt treatment also indicated activation of apoptosis in GBM tumor tissue. The expression of $p 53$ and caspase- 3 protein were observed at the cross section of gliomas tumors from the control group. However, expression of p53 protein was also observed in the nuclei and cytoplasm of tumor cells. These results are related to genetic modification of the wild type of p53 protein in glioblastoma. Moreover, these results confirmed the previously demonstrated accumulation in the cytoplasm of the wild type p53 in breast carcinomas, gliomas and undifferentiated neuroblastomas [36-38]. However, the differences between the expression level at mRNA and protein levels of p53 and caspase- 3 might be associated with different sensitivity of the methods. The evaluations of mRNA expression level are quantitative and qualitative techniques, while the protein expression analyses, like immunofluorescent staining, are only qualitative. The obtained results confirm previous findings concerning C6 GBM cell death by activation of an apoptotic mechanism instead of necrosis [6]. Moreover, the present results are in accordance with previously demonstrated anticancer properties of NP-Pt against cancer cell lines including HepG2, MCF-7 and HT29, where nanoplatinum caused lethal DNA damage of cells and induced apoptosis [22-24].
In conclusion, the U87 glioma cells treated with NP-Pt showed morphological deformations, DNA damage, and decreased metabolic activity, and also showed genotoxic effects. Moreover, the observed activation of apoptosis was higher after the NP-Pt compared with cisplatin treatment of U87 GBM. The in ovo studies showed that NP-Pt treatment decreased the weight and volume of tumors. Comparing the NP-Pt with cisplatin treatment, NP-Pt showed direct interaction with mitochondria, but also activation of the molecular apoptosis pathways, as observed by upregulation of caspase- 3 and $p 53$ gene expression. Consequently, NP-Pt have strong anticancer properties, but potential side effects must be elucidated in in vivo follow-up research.

\section{Acknowledgments}

This work was supported by the Polish National Research Council Grant Preludium NCN 2013/09/N/NZ9/01895. This report is part of Marta Kutwin's PhD thesis.

\section{Conflict of interest}

The authors declare no conflict of interest.

\section{References}

1. CBTRUS: Statistical Report: Primary Brain Tumors in the United States 1998-2002. Hinsdale, IL; 2005-2006.

2. Nieder C, Grosu AL, Astner S, Molls M. Treatment of unresectable glioblastoma multiforme. Anticancer Res 2005; 25: 4605-10.

3. Sangra M, Thorp N, May P, Pizer B, Mallucci C. Management strategies for recurrent ependymoma in the paediatric population. Childs Nerv Syst 2009; 25: 1283-91.

4. Boulikas T, Vougiouka M. Recent clinical trials using cisplatin, carboplatin and their combination chemotherapy drugs. Oncol Rep 2004; 11: 559-95.

5. Asharani PV, Xinyi N, Hande MP, Valiyaveettil S. DNA damage and p53-mediated growth arrest in human cells treated with platinum nanoparticles. Nanomedicine 2010; 5: 51-64.

6. Lopez T, Figueras F, Manjarrez J, et al. Catalytic nanomedicine: a new field in antitumor treatment using supported platinum nanoparticles. In vitro DNA degradation and in vivo tests with $\mathrm{C} 6$ animal model on Wistar rats. Eur J Medic Chem 2011; 45: 1982-90.

7. Rabik CA, Dolan ME. Molecular mechanisms of resistance and toxicity associated with platinating agents. Cancer Treat Rev 2007; 33 Suppl 1: 9-23.

8. Shen DW, Pouliot LM, Hall MD, Gottesman MM. Cisplatin resistance: a cellular self-defense mechanism resulting from multiple epigenetic and genetic changes. Pharmacol Rev 2012; 64: 706-21.

9. Wakai S, Hirokawa N. Development of the blood-brain barrier to horseradish peroxidase in the chick embryo. Cell Tissue Res 1978; 195: 195-203.

10. Mocan T. Hemolysis as expression of nanoparticlesinduced cytotoxicity in red blood cells. BMBN 2013; 1 : 7-12.

11. Prasek M, Sawosz E, Jaworski S, et al. Influence of nanoparticles of platinum on chicken embryo develop- 
ment and brain morphology. Nanoscale Res Lett 2013; 8: 251.

12. Shiny PJ, Mukherjee A, Chandrasekaran N. Haemocompatibility assessment of synthesised platinum nanoparticles and its implication in biology. Bioprocess Biosys Eng 2014; 37: 991-7.

13. Rocha CRR, Garcia CCM, Vieira DB, et al. Glutathione de pletion sensitizes cisplatin-and temozolomide-resistant glioma cells in vitro and in vivo. Cell Death Dis 2014; 5: e1505.

14. Liu R, Chang SM, Prados M. Recent advances in the treatment of central nervous system tumors. Update on Cancer Therapeutics 2008; 3 Suppl. 1: 49-79.

15. Wakai S, Hirokawa N. Development of the blood-brain barrier to horseradish peroxidase in the chick embryo. Cell Tissue Res 1978; 195: 195-203.

16. de Boer AG, Gaillard PJ. Drug targeting to the brain Annu Rev Pharmacol Toxicol 2007; 47: 323-55.

17. De Jong WH, Borm PJ. Drug delivery and nanoparticles: applications and hazards. Int J Nanomedicine 2008; 3 : 133-49.

18. Guerra J, Burt JL, Ferrer DA, Mejia S, Jose-Yacaman M. Influence of morphology in the catalytic activity of bioconjugated platinum nanostructures. J Nanopart Res 2009; 13: 1723-35.

19. Asharani PV, Sethu S, Vadukumpully S, et al. Investigations on the structural damage in human erythrocytes exposed to silver, gold, and platinum nanoparticles. Adv Funct Mat 2010; 20: 1233-42.

20. Kutwin M, Sawosz E, Jaworski S, Kurantowicz N, Strojny B, Chwalibog A. Structural damage of chicken red blood cells exposed to platinum nanoparticles and cisplatin. Nanoscale Res Lett 2014; 9: 1-6.

21. Artelt S, Creutzenberg $\mathrm{O}$, Kock $\mathrm{H}$, et al. Bioavailability of fine dispersed platinum as emitted from automotive catalytic converters: a model study. Sci Total Environ 1999; 228: 219-42.

22. Mohammadi H, Abedi A, Akbarzadeh A, et al. Evaluation of synthesized platinum nanoparticles on the MCF-7 and HepG-2 cancer cell lines. International Nano Letters 2013; 3: 28

23. Porcel E, Liehn S, Remita $\mathrm{H}$, et al. Platinum nanoparticles: a promising material for future cancer therapy? Nanotechnology 2010; 21: 85103.

24. Gehrke H, Pelka J, Hartinger CG, et al. Platinum nanoparticles and their cellular uptake and DNA platination at non-cytotoxic concentrations. Arch Toxicol 2011; 85: 799-812

25. Kondo S, Yin D, Morimura T, Kubo H, Nakatsu S, Takeuchi J. Combination therapy with cisplatin and nifedipine induces apoptosis in cisplatin-sensitive and cisplatin-resistant human glioblastoma cells. Br J Cancer 1995; 71 282-9.

26. Jaworski S, Sawosz E, Grodzik M, et al. In vitro evaluation of the effects of graphene platelets on glioblastoma multiforme cells. Int J Nanomedicine 2013; 8: 413-20.

27. Hinzmann M, Jaworski S, Kutwin M, et al. Nanoparticles containing allotropes of carbon have genotoxic effects on glioblastoma multiforme cells. Int J Nanomedicine 2014; 9: 2409-17.

28. Końca K, Lankoff A, Banasik A, et al. A cross-platform public domain PC image-analysis program for the comet assay. Mutat Res 2003; 534: 15-20.

29. Grodzik M, Sawosz E, Wierzbicki M, et al. Nanoparticles of carbon allotropes inhibit glioblastoma multiforme angiogenesis in ovo. Int J Nanomedicine 2011; 6: 3041-8.
30. Cemazar M, Milacic R, Miklavcic D, Dolzan V, Sersa G. Intratumoral cisplatin administration in electrochemotherapy: antitumor effectiveness, sequence dependence and platinum content. Anti-Cancer Drugs 1998; 9: 525-30.

31. Sandu N, Schaller B. Molecular imaging of stem cell therapy in brain tumors: a step towards personalized medicine. Arch Med Sci 2012; 8: 601-5.

32. Schaller BJ, Modo M, Buchfelder M. Molecular imaging of brain tumors: a bridge between clinical and molecular medicine? Mol Im Biol 2007; 9: 60-71.

33. Calogero A, Porcellini A, Lombari V, et al. Sensitivity to cisplatin in primary cell lines derived from human glioma correlates with levels of EGR-1 expression. Cancer Cell Int 2011; 11: 5.

34. Acosta E. Bioavailability of nanoparticles in nutrient and nutraceutical delivery. Curr Opin Coll Interface Sci 2009; 14 Suppl. 1: 3-15.

35. Jawaid P, Rehman Mu, Yoshihisa Y, et al. Effects of SOD/ catalase mimetic platinum nanoparticles on radiation-induced apoptosis in human lymphoma U937 cells. Apoptosis 2014; 19 Suppl. 6: 1006-16.

36. Moll UM, Riou G, Levine AJ. Two distinct mechanisms alter p53 in breast cancer: mutation and nuclear exclusion. Proc Natl Acad Sci U S A 1992; 89: 7262-6.

37. Ali IU, Schweitzer JB, Ikejiri B, Saxena A, Robertson JT, Oldfield EH. Heterogeneity of subcellular localization of p53 protein in human glioblastomas. Cancer Res 1994; 54: $1-5$.

38. Sembritzki O, Hagel C, Lamszus K, Deppert W, Bohn W. Cytoplasmic localization of wild-type p53 in glioblastomas correlates with expression of vimentin and glial fibrillary acidic protein. Neuro Oncol 2002; 4: 171-8. 